\title{
Research Paper Supply chain management of milk in Patna dairy project (Bihar)
}

\section{N. K. KALE, S. S. NIMBALKAR AND T. S. SONAWANE}

See end of the paper for authors' affiliations

Correspondence to :

\section{N. K. KALE}

Department of Agricultural

Economics and Statistics, College of Agriculture, PUNE (M.S.) INDIA

Paper History :

Received : 22.05.2017;

Revised : 16.08.2017;

Accepted : 23.08 .2017
ABSTRACT : In this study, an attempt has been made to study analysis of Procurement of raw milk for Patna Dairy project is done from the rural areas of five districts of Bihar through one channel only. Marketing of liquid milk is done in the town parts of the five districts of Bihar through two channels. Every producer has their own cattle and buffaloes. Jersey breed of cows are highest in number (52\%) while in case of buffaloes, local breeds (72\%) still wins the race. About 80 per cent of the producers purchase cattle feed, 'Sudhadaan' for their cattle, which is manufactured by PDP.Only 20 per cent of the producers have used artificial insemination provided by the PDP. Still only 33 per cent of the producers have attended the training programmes conducted by PDP.Only 10 per cent of the consumers are well aware of the toll free consumer's help line number.

KEY Words : Supply chain, Milk, Dairy

How To Cite This PAper : Kale, N.K. Nimbalkar, S.S. and Sonawane, T.S. (2017).Supply chain management of milk in Patna dairy project (Bihar). Internat. Res. J. Agric. Eco. \& Stat., 8 (2) : 409-413, DOI : 10.15740/HAS/ IRJAES/8.2/409-413. 